\title{
Bark extract of Cassia sieberiana DC. (Caesalpiniaceae) displayed good antibacterial activity against MDR gram- negative phenotypes in the presence of phenylalanine-arginine $\beta$-naphthylamide
}

Marilene M. M. Ambadiang1,2, Brice C. K. Atontsa³, Simplice B. Tankeo', Paul Nayim', Brice E. N. Wamba1', Gabin T. M. Bitchagno ${ }^{3,4}$, James D. S. Mpetga ${ }^{3}$, Veronique B. Penlap ${ }^{2}$ and Victor Kuete ${ }^{1 *}$ (D)

\begin{abstract}
Background: Multidrug-resistant (MDR) bacteria remain a major cause of morbidity and mortality globally. The present study was designed to investigate the in vitro antibacterial activities of crude methanol extract and constituents isolated by Column Chromatography (CC) from Cassia sieberiana bark (CSB) against ten MDR Gramnegative bacteria, as well as the mechanisms of action of the most active sample.

Methods: The antibacterial activity of the tested samples (extract, the fractions and their compounds isolated by $\mathrm{CC}$ and the structures obtained by exploiting ${ }^{1} \mathrm{H}$ and ${ }^{13} \mathrm{C}$ Nuclear magnetic resonance (NMR) spectra) in the presence and absence of an efflux pumps inhibitor, phenylalanine-arginine $\beta$-naphthylamide (PABN), was evaluated using the micro-dilution method. The effects of the most active sample were evaluated on the cell growth kinetic and on the bacterial $\mathrm{H}^{+}$-ATPase proton pumps.

Results: Phytochemical composition of the crude extract showed a rather selective distribution of secondary metabolites (presence of polyphenols, tannins, steroids, triterpenes, flavonoids, alkaloids, saponins and absence of anthocyanins, anthraquinones). The tested samples displayed different antibacterial activities with minimal inhibitory concentrations (MICs) ranging from 64 to $512 \mu \mathrm{g} / \mathrm{mL}$. Crude extract (CS) and fraction CSc showed the highest inhibitory spectra, both inhibiting all of the studied bacteria except Enterobacter aerogenes EA27 strain. Fraction CSC exerted bactericidal effects on most bacteria meanwhile, crude extract (CS) and sub-fraction CSc2 exerted bacteriostatic effects. Compounds 1 (spectaline) and 2 (iso-6-cassine) inhibited the growth of 70\% (Escherichia coli ATCC8739 and AG102, Klebsiella pneumoniae ATCC11296, Enterobacter aerogenes ATCC13048 and EA27, Providencia stuartii ATCC29916, Pseudomonas aeruginosa PA01) and 60\% (Escherichia coli ATCC8739, Klebsiella pneumoniae ATCC11296 and KP55, Providencia stuartii ATCC29916, Pseudomonas aeruginosa PA01 and PA124) of bacteria respectively with MICs ranging from 128 to $512 \mu \mathrm{g} / \mathrm{mL}$. In the presence of PAßN, the activities of crude extract CS, (Continued on next page)
\end{abstract}

\footnotetext{
* Correspondence: kuetevictor@yahoo.fr

'Department of Biochemistry, University of Dschang, P.O. Box 67, Dschang, Cameroon

Full list of author information is available at the end of the article
}

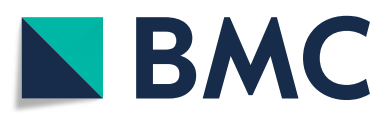

( ) The Author(s). 2020 Open Access This article is licensed under a Creative Commons Attribution 4.0 International License, which permits use, sharing, adaptation, distribution and reproduction in any medium or format, as long as you give appropriate credit to the original author(s) and the source, provide a link to the Creative Commons licence, and indicate if changes were made. The images or other third party material in this article are included in the article's Creative Commons licence, unless indicated otherwise in a credit line to the material. If material is not included in the article's Creative Commons licence and your intended use is not permitted by statutory regulation or exceeds the permitted use, you will need to obtain permission directly from the copyright holder. To view a copy of this licence, visit http://creativecommons.org/licenses/by/4.0/. The Creative Commons Public Domain Dedication waiver (http://creativecommons.org/publicdomain/zero/1.0/) applies to the data made available in this article, unless otherwise stated in a credit line to the data. 
(Continued from previous page)

fraction CAC and sub-fraction CSC2 strongly increased on most bacteria strains as their MICs significantly decreased. Sub-fraction CSc2 inhibited the $\mathrm{H}^{+}$-ATPase proton pumps and altered growth kinetic of Escherichia coli ATCC8739.

Conclusion: The overall results justify the traditional use of $C$. sieberiana for the treatment of bacterial infections.

Keywords: Cassia sieberiana, Gram negative bacteria, Multidrug resistance, Efflux pumps, Infectious diseases

\section{Background}

Infectious diseases cause 15 million deaths each year, accounting for approximately $27.12 \%$ of deaths worldwide [1]. They are involved in about responsible for 560,000 of the 2.7 million neonatal death registered each year [2]. The discovery of antibiotics reduced considerately the mortality rate associated with bacterial infections. Unfortunately, their inappropriate use led to the development of bacterial resistance known as antibioresistance. Multidrug-resistant (MDR) bacteria remain a major cause of treatment failure leading to more and more morbidity and mortality associated with infectious diseases [3]. Gram-negative bacteria such as many Enterobacteria and Pseudomonas are the most resistant groups of bacteria [4]. They express their resistance mostly using efflux pumps and the major family implicated in this resistance is the Resistance Nodulation-Cell Division (RND) which is a tripartite complex. This situation is alarming because MDR bacteria reduce the amount of antibiotics available for antibiotherapy and are responsible for therapeutic failures, hence leading to an increase in disease burden [3]. The search for new molecules to tackle bacterial antibio-resistance has become imperative. Plant kingdom has a great number of bioactive substances, and good numbers of medicinal plants from the flora of Cameroon have proven their ability to inhibit the growth of Gram-negative bacteria, including MDR phenotypes [5-9]. C. sieberiana (Caesalpiniaceae) is widespread in West Africa and is very common in all savannah woodlands or shrubs of the Sudanian zones up to the edge of the Guinean forest in Casamance. This plant is widely used in traditional medicine as an analgesic in dysmenorrhea, body pain in humans, microbial infections and in veterinary medicine [10]. In the present work, we investigated the antibacterial activity of the crude extract from C. sieberiana DC (Caesalpiniaceae) and its constituents isolated by CC and the structures obtained by exploiting ${ }^{1} \mathrm{H}$ and ${ }^{13} \mathrm{C}$ NMR spectra. The role of bacterial efflux pumps in resistance to the tested samples as well as the antibacterial mode of action were also evaluated.

\section{Methods}

\section{Chemicals}

The antibiotic, chloramphenicol $(\mathrm{CHL}) \geq 98 \%$ was used as reference drug while $p$-iodonitrotetrazolium chloride
(INT) and phenylalanine-arginine $\beta$-naphthylamide $(\mathrm{PA} \beta \mathrm{N}) \geq 97 \%$ were used as microbial growth indicator and efflux pumps inhibitor (EPI) respectively. All these chemicals were provided from Sigma-Aldrich, St. Quentin Fallavier, France. Dimethyl sulfoxide (DMSO, Sigma-Aldrich) at the final concentration of $2.5 \%$ was used to dissolve the tested samples.

\section{Plant material and extraction}

The bark of C. sieberiana DC (Caesalpiniaceae) used in this study was collected in Bandjoun Division, West Region of Cameroon. This plant was identified at the National Herbarium (Yaounde, Cameroon) where a voucher speciment was deposited under the reference number 40152/SFR/CAM/NHC.

The air dried and powdered bark $(2.5 \mathrm{~kg})$ was extracted with $5.5 \mathrm{~L}$ of methanol $(\mathrm{MeOH}) 95 \%$ for $72 \mathrm{~h}$ at room temperature. After filtration using Whatman $\mathrm{N}^{\circ} 1$ filter paper, the filtrate was concentrated in vacuum, under reduced pressure to yield a crude extract (CSB; $195.7 \mathrm{~g})$. It was then conserved at $4{ }^{\circ} \mathrm{C}$ for further use.

\section{Preliminary phytochemical screening}

Preliminary phytochemical assay was performed to detect the presence of the major classes of secondary metabolites in the crude extract, namely alkaloids, flavonoids, phenols, saponins, tannins, anthocyanins, anthraquinones, sterols and triterpenes, using a common phytochemical method previously described $[11,12]$.

\section{Isolation of the plant constituents}

A portion of $167.5 \mathrm{~g}$ of CSB was subjected to liquidliquid extraction by adding ethyl acetate (EtOAc) to the aqueous solution of the crude extract to yield $73.5 \mathrm{~g}$ and a residue $(90.5 \mathrm{~g})$. The EtOAc extract $(70 \mathrm{~g})$ was subjected to silica gel column chromatography $(0.200$ $0.500 \mathrm{~mm}$ ) eluted with gradients of $n$-hexane-EtOAc and EtOAc-MeOH as mobile phases (100:0, 90:10, 80:20, 70: $30,60: 40$ and 50:50). Seventy-five (75) fractions of 300 $\mathrm{mL}$ each were collected and combined based on their TLC profiles into three main fractions namely CSBa (20.5 g), CSBb (25.5 g) and CSBc (22.5 g) (see Table S1; supplementary files SF1). Fraction CSBb was purified by column chromatography over silica gel $(0.063-0.200$ $\mathrm{mm})$ using a gradient of $n$-hexane-EtOAc (100:00, 95:05, 90:10, 85:15, 80:20, 75:25 and 00:100) to afford arachidic 
acid $(5,18.0 \mathrm{mg})$ at $n$-hexane-EtOAc $75: 25$ and monobehenin $(4,18.0 \mathrm{mg})$ at $n$-hexane-EtOAc 70:30. Fraction CSBC was purified through silica gel $(0.063-0.2 \mathrm{~mm})$ and Sephadex gel (LH-20) chromatography successively and afforded three sub-fractions CSBc1 [(13.5 mg): 7-15], CSBc2 [(11.3 mg): 16-25] and CSBc3 [(12.4 mg): 61-66]. Purification of CSBc was made by column chromatography over silica gel $(0.063-0.200 \mathrm{~mm})$ using a gradient of EtOAc-MeOH (100:00, 95:05, 90:10, 85:15, 80:20, 75: 25 and $00: 100)$ to afford sitosterol 3-O- $\beta$-D-glucopyranoside $(6,18.0 \mathrm{mg})$, spectaline $(1,22.0 \mathrm{mg})$ and iso-6-cassine $(2,18.0 \mathrm{mg})$. The liquid-liquid extraction residue $(87.0 \mathrm{~g})$ was subjected to silica gel column chromatography $(0.200-0.500 \mathrm{~mm})$ eluted with gradients of EtOAc-MeOH (100:0, 90:10, 80:20, 70:30, 60:40 and 50: $50)$ to afford 3-O-methyl-chiro-inositol (3, $30.0 \mathrm{mg}$ ). Figure 1 shows the chemical structures of the isolated compounds. The ${ }^{1} \mathrm{H}$ and ${ }^{13} \mathrm{C}$ NMR spectra and major chemical shifts of these compounds are shown in the supplementary files (SF2).

\section{Antibacterial assay}

\section{Culture media and bacterial strains}

The Mueller Hinton Agar (MHA) was used for the activation of the bacterial strains while Mueller Hinton Broth (MHB) was used for antimicrobial assays.

Ten bacterial strains made of drug sensitive and MDR Gram-negative strains expressing efflux pumps, including reference strains (provided by American Type Culture Collection) and clinical isolates (Laboratory collection) of Escherichia coli, Pseudomonas aeruginosa, Klebsiella pneumoniae, Enterobacter aerogenes and Providencia stuartii, were used. Their bacterial features CSB are summarized in Table 1 . They were maintained on agar slant at $4{ }^{\circ} \mathrm{C}$ and cultured on a fresh appropriate agar plate $24 \mathrm{~h}$ prior to any antimicrobial test.

\section{Bacterial susceptibility determination}

The minimal inhibitory concentrations (MIC) of samples on the studied bacteria strains were determined using a rapid INT colorimetric assay $[18,19]$. Briefly, the test samples were first dissolved in DMSO/MHB mixture. The obtained solution was then added to MHB, and serial twofold dilutions carried out (in a 96-well microplate). One hundred microliters $(100 \mu \mathrm{L})$ of bacterial inoculum $\left(1.5 \times 10^{8} \mathrm{CFU} / \mathrm{mL}\right)$ were then added. The plates were covered with a sterile plate sealer, then agitated to mix the contents in the wells using a shaker and incubated at $37^{\circ} \mathrm{C}$ for $18 \mathrm{~h}$. The final concentration of DMSO was lower than $2.5 \%$ and does not affect microbial growth. Wells containing $\mathrm{MHB}, 100 \mu \mathrm{L}$ of inoculums, and DMSO at a final concentration of $2.5 \%$ served as a negative control. Chloramphenicol was used as reference antibiotic. The MIC of samples were detected after $18 \mathrm{~h}$ of incubation at $37^{\circ} \mathrm{C}$, following addition $(40 \mu \mathrm{L})$ of $0.2 \mathrm{mg} / \mathrm{mL}$ INT and incubation at $37^{\circ} \mathrm{C}$ for $30 \mathrm{~min}$ [20]. Viable bacteria reduced the yellow dye to pink. MIC was defined as the lowest sample concentration that prevented this change and exhibited complete inhibition of microbial growth. To determine the<smiles>CC(=O)CCCCCCC1CC[C@@H](O)C(C)N1</smiles><smiles>CC(=O)CCC(C)(C)CCCC1CC[C@@H](O)[C@H](C)N1</smiles><smiles>COC1C(O)C(O)C(O)C(O)C1O</smiles><smiles>CCCC(C)(C)CC(=O)OCC(O)CO</smiles>

3<smiles>CCCC(C)(C)CCC(=O)O</smiles>

5

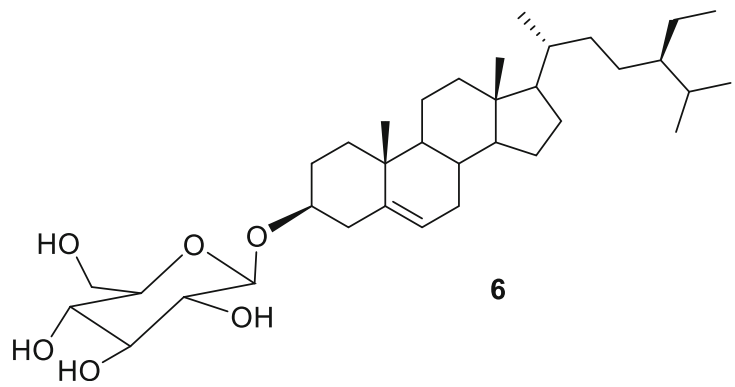

Fig. 1 Chemical structures of compounds isolated from Cassia sieberianaSpectaline (1), iso-6-cassine (2), 3-0-methyl-chiro-inositol (3), monobehenin (4), arachidic acid (5), sitosterol3-O- $\beta$-D-glucopyranoside (6). 
Table 1 Characteristics of the studied bacterial strains

\begin{tabular}{|c|c|c|c|}
\hline Species & Types & Characteristics & References \\
\hline \multirow[t]{2}{*}{ Escherichia coli } & ATCC 8739 & Reference strain & [13] \\
\hline & AG102 & $\triangle \mathrm{acr} A B$ mutant $A G 100$, owing acrF gene markedly overexpressed;TET ${ }^{R}$ & [13] \\
\hline \multirow[t]{2}{*}{ Klebsiella pneumoniae } & ATCC 11296 & Reference strain & {$[14]$} \\
\hline & KP55 & Clinical MDR isolate Tet', Ampr', Atm ${ }^{r}$, Cef $^{r}$ & [14] \\
\hline \multirow[t]{2}{*}{ Pseudomonas aeruginosa } & PA01 & Reference strain & {$[15]$} \\
\hline & PA124 & MDR clinical isolate expressing Mex efflux pump & {$[15]$} \\
\hline \multirow[t]{2}{*}{ Enterobacter aerogenes } & ATCC13048 & Reference strain & [13] \\
\hline & EA 27 & $\begin{array}{l}\text { Clinical MDR isolate exhibiting energy-dependent norfloxacin and } \\
\text { chloramphenicol efflux with Kan'r, Ampr', Nal', Strr, Tet }\end{array}$ & [16] \\
\hline \multirow[t]{2}{*}{ Providencia stuartii } & ATCC29916 & Reference strain & {$[17]$} \\
\hline & PS 2636 & Clinical MDR isolate, AcrAB-TolC & {$[17]$} \\
\hline
\end{tabular}

Ofxa ${ }^{r}, \mathrm{Kan}^{\mathrm{r}}, \mathrm{Tet}^{\mathrm{r}}, \mathrm{Erm}^{\mathrm{r}}, \mathrm{Amp}^{\mathrm{r}}, \mathrm{Nal}^{\mathrm{r}}, \mathrm{Str}^{\mathrm{r}}, \mathrm{Atm}^{\mathrm{r}}, \mathrm{Cef}^{\mathrm{r}}, \mathrm{Cip}^{\mathrm{r}}, \mathrm{Im} / \mathrm{CSB}^{\mathrm{r}}, \mathrm{Chl}^{\mathrm{r}}, \mathrm{Gen}^{\mathrm{r}}$, Nis${ }^{\mathrm{r}}$, Flx${ }^{\mathrm{r}}$ : resistant (r) to ofloxacin, kanamycin, tetracyclin, erythromycin, ampicillin, nalidixic acid, streptomycin, aztreoname, cefepim, ciprofloxacin, imipenem/Cilastatin sodium, chloramphenicol, gentamycin, nisine and flomoxef respectively; MDR: Multidrug-resistant;. AcrAB-To/C, AcrAB and Mar A are efflux pumps

minimal bactericidal concentrations (MBC), a volume of $150 \mu \mathrm{L}$ of MHB was introduced in a new 96-well microplate, following addition of $50 \mu \mathrm{L}$ of the previous well's microplate contents where no microbial growth was observed and which did not receive the INT (during the reading of the MIC). After $48 \mathrm{~h}$ incubation at $37^{\circ} \mathrm{C}$, the $\mathrm{MBC}$ of each sample was determined and defined by adding $40 \mu \mathrm{L}$ of $0.2 \mathrm{mg} / \mathrm{mL}$ INT as previously described. Samples were tested alone and latter, in the presence of $\mathrm{PA} \beta \mathrm{N}$, an efflux pump inhibitor, at 30 $\mathrm{mg} / \mathrm{L}$ final concentration. In this last case, the activity improvement factors (AIFs) were determined to qualify the potentiation level of this inhibitor on the activity of sample, using the MICsample alone/MICsample-$P A B N$ combination ratio. All assays were performed in triplicate and repeated thrice.

\section{Antibacterial mechanisms of action \\ Effect of sub-fraction CSBC2 on bacterial growth kinetic}

Bacterial growth kinetic study of sub-fraction CSBc2 which showed the best antibacterial activity was done using a spectrophotometer at $600 \mathrm{~nm}$ wavelength [21]. Bacterium used for this study was a reference strain Escherichia coli ATCC8739 and the sample was tested at the concentrations of $\mathrm{MIC} / 2$, MIC and $2 \mathrm{MIC}$. Firstly, $500 \mu \mathrm{L}$ of bacterial suspension $\left(1.5 \times 10^{8} \mathrm{UFC} / \mathrm{ml}\right)$ from preculture were added to $450 \mathrm{~mL}$ MHB $(1 / 100 \mathrm{v} / \mathrm{v}$ dilution) and incubated at $37^{\circ} \mathrm{C}$ for $18 \mathrm{~h}$ under magnetic agitation and in the presence of tested sample at different concentrations. Chloramphenicol was used as positive control whereas, inoculum $\left(1.5 \times 10^{8} \mathrm{UFC} / \mathrm{mL}\right) /$ DMSO $(2.5 \% \mathrm{v} / \mathrm{v})$ mixture constituted the negative control. At $0,0.5,1$ and $2 \mathrm{~h}$ followed by regular interval time of $2 \mathrm{~h}$ from 2 to $18 \mathrm{~h}$, aliquots of $1 \mathrm{~mL}$ from the preparation were deducted and introduced in a spectrophotometric tab and then, the optical density (OD) was read at a wavelength of $600 \mathrm{~nm}$. The bacterial growth curves $[\mathrm{OD}=\mathrm{f}$ (time) $]$ were plotted using Microsoft Excel software (Fig. 1).

\section{Effect of sub-fraction CSBC2 on bacterial $\mathrm{H}^{+}$-ATPase- dependent proton pumps}

The ability of sub-fraction CSBc2 to inhibit bacterial $\mathrm{H}^{+}$-ATPase-dependent proton pumps was evaluated, by assessing the acidification of the bacterial external environment, through $\mathrm{pH}$ measurement, as previously described [22]. Hence, a fresh bacterial colony was dissolved in $20 \mathrm{~mL}$ of MHB culture medium and incubated at $37^{\circ} \mathrm{C}$ under magnetic agitation for $18 \mathrm{~h}$. Aliquots of $1 \mathrm{~mL}$ from this bacterial preculture were deducted and added to MHB to afford $100 \mathrm{~mL}$ final volume $(1 / 100 \mathrm{v} / \mathrm{v}$ dilution), and then re-incubated at $37^{\circ} \mathrm{C}$ for $18 \mathrm{~h}$ under magnetic agitation. One hundred milliliter $(100 \mathrm{~mL})$ from this bacterial culture was centrifuged at $4000 \mathrm{rds} / \mathrm{min}$ for $30 \mathrm{~min}$ at $4{ }^{\circ} \mathrm{C}$. Recuperated gut was washed with sterile distilled water then with $\mathrm{KCl} 50 \mathrm{mM}$ and was dissolved in $50 \mathrm{~mL} \mathrm{KCl} 50$ $\mathrm{mM}$. The obtained bacterial suspension was conserved at $4{ }^{\circ} \mathrm{C}$ for $18 \mathrm{~h}$ (for glucose starvation), after which the $\mathrm{pH}$ was adjusted to 7.3 by adding $\mathrm{HCl}$ or $\mathrm{NaOH}$ solution. Then, $0.5 \mathrm{~mL}$ of tested sample was added to $4 \mathrm{~mL}$ of this bacterial culture and the mixture was incubated at $37^{\circ} \mathrm{C}$ for $10 \mathrm{~min}$, after which, $0.5 \mathrm{~mL}$ of glucose $20 \%$ was added in order to initiate the acidification of the environment. Inoculum $\left(1.5 \times 10^{8} \mathrm{UFC} /\right.$ $\mathrm{mL}) / \mathrm{DMSO}(2.5 \% \mathrm{v} / \mathrm{v})$ mixture constituted the negative control. The $\mathrm{pH}$ values of tested samples at different concentrations were read at room temperature $\left(25^{\circ} \mathrm{C}\right)$ each $10 \mathrm{~min}$ for $1 \mathrm{~h}$, using a $\mathrm{pH}$-meter. The curves $[\mathrm{pH}=\mathrm{f}$ (time)] were labeled using Microsoft Excel software (Fig. 2). 


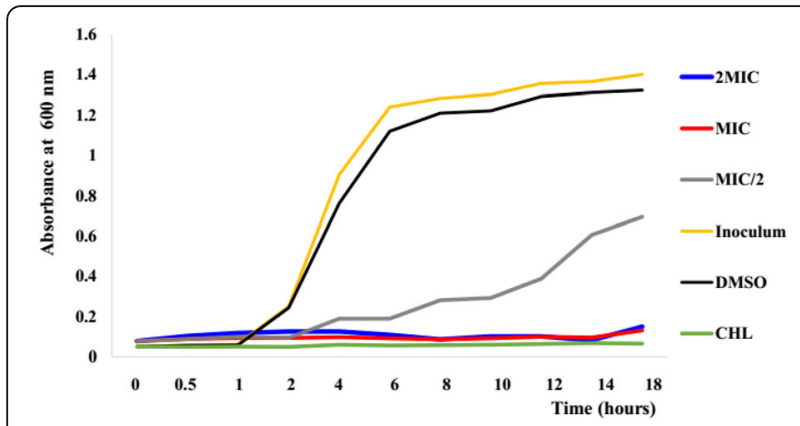

Fig. 2 Effect of sub-fraction CSBC2 at different concentrations on growth kinetic of Escherichia coli ATCC8739

\section{Data analysis}

The plant crude extract, fractions and sub-fractions were considered significantly active when their MIC values were below to $100 \mu \mathrm{g} / \mathrm{mL}$, moderately active when the MIC values were found between 100 and $625 \mu \mathrm{g} / \mathrm{mL}$ and poorly active when the MIC values were above $625 \mu \mathrm{g} /$ $\mathrm{mL}$; for antibiotics and isolated compounds, sample with $\mathrm{MIC} \leq 10 \mu \mathrm{g} / \mathrm{mL}, 10<\mathrm{MIC} \leq 100 \mu \mathrm{g} / \mathrm{mL}$ or $\mathrm{MIC}>100 \mu \mathrm{g} /$ $\mathrm{mL}$ is considered to have strong, moderate or weak activity respectively [23]. When $\mathrm{MBC} / \mathrm{MIC}$ ratio was $\leq 4$, tested samples were considered as bactericidal and when this ratio was $>4$, samples were considered as bacteriostatic [24]. During the evaluation of the antibacterial activity in the presence or absence of an efflux pumps inhibitor, the activity improvement factors (AIFs) were calculated. The activity of an extract, fraction or sub-fraction was considered to be improved when AIF was $\geq 2$ [25].

\section{Results}

\section{Antibacterial activity of crude extract, fractions and compounds}

The antibacterial susceptibility of tested samples was carried determining the MIC and $\mathrm{MBC}$ of each sample on studied bacteria (Tables 2, 3 and 4). Bactericidal or bacteriostatic effects of each sample on a bacterial strains were determined by calculating the $\mathrm{MBC} / \mathrm{MIC}$ ratio. Results presented in Table 2 show that crude extract CSB and fraction CSBc were the best botanicals since they displayed recordable MIC against 90\% (9/10) of studied strains with values ranging from 128 to $512 \mu \mathrm{g} / \mathrm{mL}$. They were not active only against Enterobacter aerogenes EA27 and their best activity was against Klebsiella pneumoniae KP55. Fractions CSBa and CSBb which were less active inhibited the growth of 30\% (3/ $10)$ and $20 \%(2 / 10)$ of bacteria respectively. All these samples showed a bactericidal effect against susceptible bacterial strains. In Table 3, only sub-fraction CSBc2 inhibited the growth of many bacteria $(70 \%(7 / 10))$ with MIC ranging from 128 to $256 \mu \mathrm{g} / \mathrm{mL}$. The other sub- fractions displayed antibacterial activities against 30\% (3/ 10) of studied bacteria. All sub-fractions had bacteriostatic effects against all tested bacteria, excepted subfraction $\mathrm{CSBC} 2$ which showed bactericidal effect against Escherichia coli ATCC8739 and Pseudomonas aeruginosa PA124. Furthermore, only compounds 1 and 2 of the six isolated compounds showed antibacterial activity respectively on $70 \%(7 / 10)$ and $60 \%(6 / 10)$ of strains with MIC ranging from 128 to $512 \mu \mathrm{g} / \mathrm{mL}$ (Table 4). Compound 1 exhibited a bactericidal effect against Escherichia coli ATCC8739 and Enterobacter aerogenes EA27 while compound 2 showed this effect against Escherichia coli ATCC8739. Other compounds showed weak or no activity against studied bacteria.

Samples were also tested in presence of an efflux pump inhibitor in order to determine their role in the mechanism of resistance of studied bacterial strains (Table 5).

\section{Role of efflux pumps on the resistance of bacteria to the tested samples}

In the presence of PA $\beta N$ (Table 5), the activity of all tested samples against many bacteria increased considerably. The activities of crude extract CSB, fraction CSAc, sub-fraction $\mathrm{CSBC} 2$ and sub-fraction $\mathrm{CSBc} 3$ were improved respectively on $70 \%$ (7/10), 80\% (8/10), 70\% (7/ $10)$ and $60 \%(6 / 10)$ of studied bacteria, AIFs ranged from 2 to $>128$. The activity of sub-fraction CSBc1 was improved only against 30\% (3/10) of bacteria. Pseudomonas aeruginosa strains were more sensitive vis-a-vis chloramphenicol and sub-fraction $\mathrm{CSBc} 3$ and more resistant towards other samples, whereas Escherichia coli strains were resistant towards these two substances (chloramphenicol and sub-fraction $\mathrm{CSBC} 3$ ) and sensitive towards other samples.

Second metabolites classes detected in the crude extract Phytochemical analysis of $C$. sieberiana crude extract showed the presence of polyphenols, flavonoids, tannins, alkaloids, saponins, steroids and triterpenes. Anthraquinones and anthocyanin were absent (Table 6).

\section{Effect of sub-fraction CSBC2 on the bacterial growth kinetic}

Data depicted in Fig. 2 show the growth of Escherichia coli ATCC8739 in absence and presence of sub-fraction $\mathrm{CSBC} 2$ at different concentrations (MIC/2, MIC and $2 \mathrm{x}$ $\mathrm{MIC}$ ) and chloramphenicol (at MIC) during a time range. This figure showed three stages (lag, exponential and stationary stages) of bacterial growth for negative controls (inoculum and DMSO 2.5\%). Lag phase is prolonged till the 18th hour in the presence of sub-fraction $\mathrm{CSBC} 2$ at $\mathrm{MIC}$ and $2 \times \mathrm{MIC}$, as well as in the presence of a reference antibiotic, chloramphenicol (CHL). At 
Table 2 Minimal inhibitory and bactericidal concentrations of crude extract, his derived fractions and chloramphenicol

\begin{tabular}{|c|c|c|c|c|c|c|c|c|c|c|c|c|c|c|c|}
\hline \multirow{3}{*}{$\begin{array}{l}\text { Bacterial } \\
\text { strains }\end{array}$} & \multicolumn{15}{|c|}{ Tested samples and concentrations $(\mu \mathrm{g} / \mathrm{mL})$} \\
\hline & \multicolumn{3}{|l|}{$\overline{\mathrm{CSB}}$} & \multicolumn{3}{|c|}{ CSBa } & \multicolumn{3}{|c|}{$\mathrm{CSBb}$} & \multicolumn{3}{|c|}{$\mathrm{CSBC}$} & \multicolumn{3}{|c|}{ Chloramphenicol } \\
\hline & MIC & MBC & $\mathbf{R}$ & MIC & MBC & $\mathbf{R}$ & MIC & MBC & $\mathbf{R}$ & MIC & MBC & $\mathbf{R}$ & MIC & MBC & $\mathbf{R}$ \\
\hline \multicolumn{16}{|l|}{ Escherichia coli } \\
\hline ATCC8739 & 512 & 512 & 1 & 512 & 512 & 1 & - & $\mathrm{nt}$ & nd & 128 & 128 & 1 & 2 & 64 & 32 \\
\hline AG102 & 512 & 512 & 1 & - & nt & nd & - & nt & nd & 512 & 512 & 1 & 32 & 256 & 8 \\
\hline \multicolumn{16}{|c|}{ Klebsiella pneumoniae } \\
\hline ATCC11296 & 512 & - & $>1$ & 512 & 512 & 1 & - & nt & nd & 512 & - & $>1$ & 32 & 256 & 8 \\
\hline KP55 & 128 & 512 & 4 & 512 & 512 & 1 & - & $\mathrm{nt}$ & nd & 128 & 512 & 4 & 64 & 256 & 4 \\
\hline \multicolumn{16}{|c|}{ Enterobacter aerogenes } \\
\hline ATCC13048 & 512 & 512 & 1 & - & $\mathrm{nt}$ & nd & - & nt & nd & 512 & 512 & 1 & 16 & 128 & 8 \\
\hline EA27 & - & $\mathrm{nt}$ & nd & - & $\mathrm{nt}$ & nd & - & $\mathrm{nt}$ & nd & - & $\mathrm{nt}$ & nd & 32 & 256 & 8 \\
\hline \multicolumn{16}{|c|}{ Providencia stuartii } \\
\hline ATCC29916 & 512 & 512 & 1 & - & $\mathrm{nt}$ & nd & 512 & 512 & 1 & 512 & 512 & 1 & 64 & 256 & 4 \\
\hline PS2636 & 512 & 512 & 1 & - & $\mathrm{nt}$ & nd & 512 & 512 & 1 & 512 & 512 & 1 & 64 & 256 & 4 \\
\hline \multicolumn{16}{|c|}{ Pseudomonas aeruginosa } \\
\hline PA01 & 512 & - & $>1$ & - & $\mathrm{nt}$ & nd & - & $\mathrm{nt}$ & nd & 512 & - & $>1$ & 64 & - & $>4$ \\
\hline PA124 & 512 & 512 & 1 & - & nt & nd & - & $\mathrm{nt}$ & nd & 512 & 512 & 1 & 64 & - & $>4$ \\
\hline PSBS (\%) & 90 & & & 30 & & & 20 & & & 90 & & & 100 & & \\
\hline
\end{tabular}

MIC minimal inhibitory concentration, $M B C$ minimal bactericidal concentration R: MBC / MIC ratio (a sample is considered as bacteriostatic or bactericidal when this ratio is $>4$ or $\leq 4$ respectively) $(-)$ : MIC or $M B C>512 \mu \mathrm{g} / \mathrm{mL}$ for crude extract and fractions and $>256$ for chloramphenicol nt: not tested nd: not determined (as no MIC and MBC values were not observed till $512 \mu \mathrm{g} / \mathrm{mL}$ ) PBSS: percentage of susceptible bacteria to substances CSB is crude extract of Cassia sieberiana $\mathrm{CSBa}, \mathrm{CSBb}$ and $\mathrm{CSBC}$ are fractions from CSB

$\mathrm{MIC} / 2$ of sub-fraction $\mathrm{CSBC} 2$, this phase persisted for 4 $\mathrm{h}$ before exponential growth phase started.

\section{Effect of sub-fraction CSBc2 on bacterial $\mathrm{H}^{+}$-ATPase- dependent proton pumps}

Figure 3 shows the variation of $\mathrm{pH}$ (acidity) of cell culture containing Escherichia coli ATCC8739, at different incubation periods in presence of sub-fraction $\mathrm{CSBC} 2$ at MIC concentration. DMSO $2.5 \%$ was used as negative control. The curves obtained showed that after $60 \mathrm{~min}$ of the experiment, the $\mathrm{pH}$ values in the presence of subfraction $\mathrm{CSBC} 2$ remained almost constant from the beginning to the end of the experiment (7.33). Meanwhile in presence of control (DMSO 2.5\%), pH values considerably decreased (from 7.33 to 5.5 ).

\section{Discussion}

The phytochemical screening of CSB showed the presence of some classes of secondary metabolites including polyphenols, alkaloids, flavonoids, saponins, tannins, steroids and triterpenes. The obtained results are in accordance with previous studies done by other authors on $C$. sieberiana bark [26-33]. The secondary metabolites contained in several medicinal dietary plants are known for their pharmacological activities including antibacterial properties [34, 35].
Following established cutoff points [23], a botanical is considered significantly active when $\mathrm{MIC}<100 \mu \mathrm{g} / \mathrm{mL}$, moderately active when $100 \leq \mathrm{MIC} \leq 625 \mu \mathrm{g} / \mathrm{mL}$ and poorly active when MIC> $625 \mu \mathrm{g} / \mathrm{mL}$. Based on these cutoff points, some of the tested samples (CSBc1, CSBc2, $\mathrm{CSBc} 3$ ) can be considered significantly active, with MIC value of $64 \mu \mathrm{g} / \mathrm{mL}$, while CSB generally displayed a moderate activity on $90 \%$ of studied bacterial strains. The phytochemical composition of CS can be responsible for the antibacterial activity of the samples, since tannins, saponins, flavonoids and steroids (reported in this fraction) are known to have antimicrobial and curative properties against several pathogens [31]. The results of antimicrobial activity obtained with the crude extract of CSB in this study corroborate those of [36] who reported the activity of the methanol extract of this plant against sensitive Gram-negative and Gram-positive bacteria, and attributed this activity to the presence of flavonoids. The MICs variability from one sample to another, could be explained either by the difference in their secondary metabolite's contents, the quantity or the quality of these metabolites [7, 37, 38].

Multidrug-resistant Gram-negative pathogens are global public health concern as therapeutic options for treating such infections are dwindling. In view of the scarcity of new antibiotics, a parallel strategy to the discovery of new molecules is the use of substances 
Table 3 Minimal inhibitory and bactericidal concentrations of different sub-fractions

\begin{tabular}{|c|c|c|c|c|c|c|c|c|c|}
\hline \multirow{3}{*}{$\begin{array}{l}\text { Bacterial } \\
\text { strains }\end{array}$} & \multicolumn{9}{|c|}{ Sub-fractions and concentrations $(\mu \mathrm{g} / \mathrm{mL})$} \\
\hline & \multicolumn{3}{|c|}{$\mathrm{CSBC1}$} & \multicolumn{3}{|c|}{$\mathrm{CSBC2}$} & \multicolumn{3}{|c|}{ CSBC3 } \\
\hline & MIC & MBC & $\mathbf{R}$ & MIC & MBC & $\mathbf{R}$ & MIC & MBC & $\mathbf{R}$ \\
\hline \multicolumn{10}{|l|}{ Escherichia coli } \\
\hline ATCC8739 & 256 & - & $>2$ & 64 & 64 & 1 & 256 & - & $>2$ \\
\hline AG102 & - & $\mathrm{nt}$ & nd & 256 & - & $>2$ & 64 & - & $>8$ \\
\hline \multicolumn{10}{|c|}{ Klebsiella pneumoniae } \\
\hline ATCC11296 & 64 & - & $>8$ & 128 & - & $>4$ & - & $\mathrm{nt}$ & nd \\
\hline KP55 & - & $\mathrm{nt}$ & nd & - & nt & nd & - & nt & nd \\
\hline \multicolumn{10}{|c|}{ Enterobacter aerogenes } \\
\hline ATCC13048 & 512 & - & $>1$ & 256 & - & $>2$ & - & nt & nd \\
\hline EA27 & - & $\mathrm{nt}$ & nd & - & nt & nd & - & $\mathrm{nt}$ & nd \\
\hline \multicolumn{10}{|c|}{ Providencia stuartii } \\
\hline ATCC29916 & - & $\mathrm{nt}$ & nd & 256 & - & $>2$ & 256 & - & $>2$ \\
\hline PS2636 & - & $\mathrm{nt}$ & nd & 256 & - & $>2$ & - & nt & nd \\
\hline \multicolumn{10}{|c|}{ Pseudomonas aeruginosa } \\
\hline PA01 & - & nt & nd & - & nt & nd & - & nt & nd \\
\hline PA124 & - & nt & nd & 128 & 128 & 1 & - & nt & nd \\
\hline PSBS (\%) & 30 & & & 70 & & & 30 & & \\
\hline
\end{tabular}

MIC minimal inhibitory concentration, $M B C$ minimal bactericidal concentration $\mathrm{R}: \mathrm{MBC}$ / MIC ratio (a sample is considered as bacteriostatic or bactericidal when this ratio is $>4$ or $\leq 4$ respectively) $(-)$ : MIC or MBC $>512 \mu \mathrm{g} / \mathrm{mL}$ nt: not tested nd: not determined (as no MIC and MBC values were not observed till $512 \mu \mathrm{g} / \mathrm{mL}$ ) PBSS: percentage of susceptible bacteria to substances CSBC1, CSBC2 and CSBC3 are sub-fractions from fraction CSBC

inhibiting bacterial resistant pathways. Therefore, only three compounds (the two alkaloids spectaline (1) and iso-6-cassine (2) and sitosterol 3-O- $\beta$-D-glucopyranoside (6)) isolated from fraction CSBc which was the most active fraction, inhibited the growth of some of the studied bacteria, but with weak activities. Indeed, (-)-iso-6-spectaline has been reported to exhibit a weak antimicrobial activity against Staphylococcus epidermidis [39]. Cassine isolated from Senna racemosa Mill. leaves (Fabaceae) showed weak antimicrobial activities against Staphylococcus aureus, Bacillus subtilis and Candida albicans [40]. Furthermore, a mixture compounds of (-)-spectaline and (-)-cassein from the flower of Senna spectabilis (DC.) Irwin \& Barneby (Fabaceae) has been reported to have anti-leishmanial properties [41]. However, to the best of our knowledge, no antibacterial study against MDR Gram-negative strains has been reported so far with these compounds.

It can be noticed from data reported in Table 5 that, efflux pumps could be responsible for the low action of some tested samples such as CSB, fraction CSBC and sub-fraction CSBC2. In effect, the modulation of their activities on some studied bacterial strains demonstrates that bioactive compounds responsible for their antibacterial activity are efflux pumps substrates and might therefore have an intracellular action site, and thus, $\mathrm{PA} \beta \mathrm{N}$ has effectively prevented the proper functioning of these efflux pumps. It can also be noted that fraction CSBc had the best modulating effect since its MICs were shown to decrease on almost all the studied bacterial strains. These results corroborate some previously reported data $[13,42]$ stating that, efflux mechanism can be blocked by various efflux pump inhibitors and this will restore the intracellular concentrations as well as the activities of antimicrobial substances. Phenylalanine arginine $\beta$-naphthylamide, used as an efflux pump inhibitor, is one of the best efflux pump inhibitors and it particularly acts on RND pumps [43-45]. The activities of some tested samples were not improved in the presence of PA $\beta \mathrm{N}$. This could result from the fact that they were not efflux pump substrates or that the efflux mechanism was not the only mechanism expressed in studied bacteria. Therefore, Pseudomonas aeroginosa strains were more resistant to most of the tested sample-PA $\beta \mathrm{N}$ combinations. It was shown that $P$. aeroginosa is a highly pathogenic microorganism responsible for multiple infections in both humans and plants. Efflux-mediated antibiotic resistance in $P$. aeruginosa is conferred primarily by efflux pumps belonging to the resistance nodulation-cell division (RND) superfamily that extrudes a broad spectrum of antimicrobial compounds and other substrates [46, 47].

Analysis of curves in Fig. 2 showed that sub-fraction CSBC2 exerted its inhibitory activity at lag phase of bacterial growth depending on the concentrations. The progress of the latent phase was disturbed when the microorganism encountered sub-fraction $\mathrm{CSB} 2$, since an extension of this phase at MIC and $2 \times$ MIC was observed throughout the experiment period. These results corroborate those obtained earlier [48], showing that the lag phase is associated with biosynthesis of many enzymes which helps a microorganism to adapt with its new environment with respect to nutritive elements present, and that any distortion of this process causes the lag phase to be prolonged. Net growth of the bacterial strains treated the latter with tested sample at MIC/2 was observed due to the presence of the molecules responsible for the antibacterial activity at a sub-inhibitory concentration. The relatively low decrease in the number of bacterial colonies after the experiment gives information on the bacteriostatic effect of the extract. This can be confirmed with the higher MBC values observed.

Sub-fraction CSBc2 was also tested on $\mathrm{H}+$-ATPasedependent proton pumps of E. coli ATCC8739 as well as on its potential to inhibit the cell growth (Fig. 3). Indeed, the energy required for the development of the metabolic reactions of the bacteria depends on the proper functioning of these $\mathrm{H}+$-ATPase-dependent proton pumps which are protein enzymes necessary for the 
Table 4 Minimal inhibitory and bactericidal concentrations of different compounds

\begin{tabular}{|c|c|c|c|c|c|c|c|c|c|c|c|c|}
\hline \multirow{3}{*}{$\begin{array}{l}\text { Bacterial } \\
\text { strains }\end{array}$} & \multicolumn{12}{|c|}{ Compounds and concentrations $(\mu \mathrm{g} / \mathrm{mL})$} \\
\hline & \multicolumn{3}{|l|}{1} & \multicolumn{3}{|l|}{2} & \multicolumn{3}{|l|}{6} & \multicolumn{3}{|c|}{ Chloramphenicol } \\
\hline & MIC & MBC & $\mathbf{R}$ & MIC & MBC & $\mathbf{R}$ & MIC & MBC & $\mathbf{R}$ & MIC & MBC & $\mathbf{R}$ \\
\hline \multicolumn{13}{|l|}{ Escherichia coli } \\
\hline ATCC8739 & 128 & 512 & 4 & 256 & - & $>1$ & 256 & - & $>2$ & 2 & 64 & 32 \\
\hline AG102 & 256 & - & $>1$ & - & nt & nd & - & nt & nd & 32 & 256 & 8 \\
\hline \multicolumn{13}{|c|}{ Klebsiella pneumoniae } \\
\hline ATCC11296 & 128 & $\mathrm{nt}$ & nd & 256 & 512 & 2 & - & nt & nd & 32 & 256 & 8 \\
\hline KP55 & - & - & $>1$ & 512 & - & $>1$ & - & $\mathrm{nt}$ & nd & 64 & 256 & 4 \\
\hline \multicolumn{13}{|c|}{ Enterobacter aerogenes } \\
\hline ATCC13048 & 128 & - & $>1$ & - & nt & nd & - & $\mathrm{nt}$ & nd & 16 & 128 & 8 \\
\hline EA27 & 128 & 512 & 4 & - & $\mathrm{nt}$ & nd & - & $\mathrm{nt}$ & nd & 32 & 256 & 8 \\
\hline \multicolumn{13}{|c|}{ Providencia stuartii } \\
\hline ATCC29916 & 128 & - & $>1$ & 256 & - & $>2$ & - & nt & nd & 64 & 256 & 4 \\
\hline PS2636 & - & nt & nd & - & nt & nd & - & nt & nd & 64 & 256 & 4 \\
\hline \multicolumn{13}{|c|}{ Pseudomonas aeruginosa } \\
\hline PA01 & 512 & - & $>1$ & 512 & - & $>1$ & 512 & nt & nd & 64 & - & $>4$ \\
\hline PA124 & - & $\mathrm{nt}$ & nd & 512 & - & $>1$ & - & $\mathrm{nt}$ & nd & 64 & - & $>4$ \\
\hline PSBS (\%) & 70 & & & 60 & & & 20 & & & 100 & & \\
\hline
\end{tabular}

MIC minimal inhibitory concentration, $M B C$ minimal bactericidal concentration R: MBC / MIC ratio (a sample is considered as bacteriostatic or bactericidal when this ratio is $>4$ or $\leq 4$ respectively) (-): MIC or MBC $>512 \mu \mathrm{g} / \mathrm{mL}$ nt: not tested nd: not determined (as no MIC and MBC values were not observed till $512 \mu \mathrm{g} / \mathrm{mL}$ ) PBSS: percentage of susceptible bacteria to substances Compounds 1, $\mathbf{2}$ and $\mathbf{6}$ were obtained from fraction CSBc Compounds $\mathbf{3}$ isolated from the residual extract and compounds $\mathbf{4}$ and $\mathbf{5}$ isolated from fraction CSBb did not showed any activity against all studied bacterial

Table 5 Minimal inhibitory concentrations of tested samples in presence of PABN

\begin{tabular}{|c|c|c|c|c|c|c|c|c|c|c|c|c|c|c|c|c|c|c|}
\hline \multirow{3}{*}{$\begin{array}{l}\text { Bacterial } \\
\text { strains }\end{array}$} & \multicolumn{18}{|c|}{ Tested samples and concentrations $(\mu \mathrm{g} / \mathrm{mL})$} \\
\hline & \multicolumn{3}{|l|}{$\overline{C S B}$} & \multicolumn{3}{|c|}{ CSBC } & \multicolumn{3}{|c|}{ CSBc1 } & \multicolumn{3}{|c|}{ CSBC2 } & \multicolumn{3}{|c|}{ CSBC3 } & \multicolumn{3}{|c|}{ Chloramphenicol } \\
\hline & $\overline{M I C}$ & $+\mathrm{PA} \beta \mathrm{N}$ & $\mathbf{R}$ & $\overline{M I C}$ & $+\mathrm{PA} \beta \mathrm{N}$ & $\mathbf{R}$ & $\overline{M I C}$ & $+\mathrm{PA} \beta \mathrm{N}$ & $\mathbf{R}$ & $\overline{M I C}$ & $+\mathrm{PA} \beta \mathrm{N}$ & $\mathbf{R}$ & $\overline{M I C}$ & $+\mathrm{PA} \beta \mathrm{N}$ & $\mathbf{R}$ & $\overline{\mathrm{MIC}}$ & $+\mathrm{PA} \beta \mathrm{N}$ & $\mathbf{R}$ \\
\hline \multicolumn{19}{|l|}{ Escherichia coli } \\
\hline ATCC8739 & 512 & 64 & 8 & 512 & 16 & 32 & 256 & 16 & 16 & 256 & 64 & 4 & 256 & 256 & 1 & 2 & $<0,5$ & $>4$ \\
\hline AG102 & 512 & 64 & 8 & 512 & 32 & 16 & - & - & nd & 256 & $<4$ & $>64$ & 64 & - & $>8$ & 32 & 4 & 8 \\
\hline \multicolumn{19}{|c|}{ Klebsiella pneumoniae } \\
\hline ATCC11296 & 512 & - & $<1$ & 512 & 128 & 4 & 64 & 16 & 4 & 256 & 128 & 2 & - & $<4$ & $>128$ & 32 & 8 & 4 \\
\hline KP55 & 128 & $<4$ & $>32$ & 128 & 256 & 0.5 & - & - & nd & - & 256 & $>2$ & - & - & nd & 64 & 32 & 2 \\
\hline \multicolumn{19}{|c|}{ Enterobacter aerogenes } \\
\hline ATCC13048 & 512 & 16 & 32 & 512 & 256 & 2 & 512 & - & $<1$ & 256 & 32 & 8 & - & $<4$ & $>128$ & 16 & 32 & 2 \\
\hline EA27 & - & 32 & $>16$ & - & $<4$ & 128 & - & 64 & $>8$ & - & 256 & $>2$ & - & - & nd & 32 & 16 & 2 \\
\hline \multicolumn{19}{|c|}{ Providencia stuartii } \\
\hline ATCC29916 & 512 & 32 & 16 & 512 & 256 & 2 & - & - & nd & 256 & 128 & 2 & 256 & 8 & 32 & 64 & 8 & 8 \\
\hline PS2636 & 512 & 32 & 16 & 512 & 128 & 4 & - & - & nd & 256 & - & $<2$ & - & - & nd & 64 & 16 & 4 \\
\hline \multicolumn{19}{|c|}{ Pseudomonas aeruginosa } \\
\hline PA01 & 512 & - & nd & 512 & - & $<1$ & - & - & nd & - & - & nd & - & $<4$ & $>128$ & 64 & 8 & 8 \\
\hline PA124 & 512 & - & nd & 512 & 256 & 2 & - & - & nd & 128 & 256 & 0,5 & - & 16 & $>32$ & 256 & 16 & 16 \\
\hline PIA (\%) & & 70 & & & 80 & & & 30 & & & 70 & & & 60 & & & 100 & \\
\hline
\end{tabular}

MIC minimal inhibitory concentration R=AIF: MICample alone / MICample ${ }_{+P A B N}$ ratio (this means the factor which determine the improvement of the activity of samples by PABN; the activity of a sample was considered to be improved when its AIF was $>2$ ). (+ PABN): represent MIC values of tested samples obtained in presence of PABN (-): MIC $>512 \mu \mathrm{g} / \mathrm{mL}$ for crude extract, fractions and sub-fractions PIA: percentage of improved activity nd: not determined (as no MIC values were not observed till $512 \mu \mathrm{g} / \mathrm{mL}$ ) CSB: crude extract CSBC: fraction CSBC1, CSBC2 and CSBC3 are sub-fractions from fraction CSBC 
Table 6 Phytochemical composition of Cassia sieberiana bark

\begin{tabular}{ll}
\hline Metabolite classes & Crude extract (CSB) composition \\
\hline Polyphenols & + \\
Flavonoids & + \\
Tannins & + \\
Anthraquinones & - \\
Alkaloids & + \\
Saponins & + \\
Steroids & + \\
Triterpenes & + \\
Anthocyanins & -
\end{tabular}

$(+)$ : presence of metabolites (-): absence of metabolites

formation of a large electrochemical gradient of protons and the maintenance of the intracellular $\mathrm{pH}$ [49]. The inhibition of the proton pumps will thus become lethal to the bacterium. The inhibition of these pumps by a substance therefore leads to a decrease in $\mathrm{H}^{+}$protons in the medium which becomes less and less acidic, indicating the inactivation of the $\mathrm{H}+$-ATPase pumps, compromising the bacterium survival that will die for lack of energy [49]. This confirmed the killing effect of subfraction CSBc2 on E. coli ATCC8739.

The data obtained in this experiment therefore indicates that sub-fraction $\mathrm{CSBc} 2$ is a potential proton pump inhibitor and corroborates those obtained by [50] revealing that proton-ATPase pumps are responsible for regulating the cytoplasm and that any inhibition of this pump equally inhibits bacterial growth. It is well known that bacteria are viable in a wide range of $\mathrm{pH}(1-11)$ and that the bacterial cytoplasmic $\mathrm{pH}$ is kept near neutral. It is also generally accepted that bacterial cytoplasmic $\mathrm{pH}$ is regulated by various cation transport systems [49]. Some data suggest that in E. coli, cytoplasmic $\mathrm{pH}$ is regulated by proton extrusion via the respiratory chain and potassium influx at acid $\mathrm{pH}$, and cation/proton antiporter regulates the $\mathrm{pH}$ in alkaline states [50].

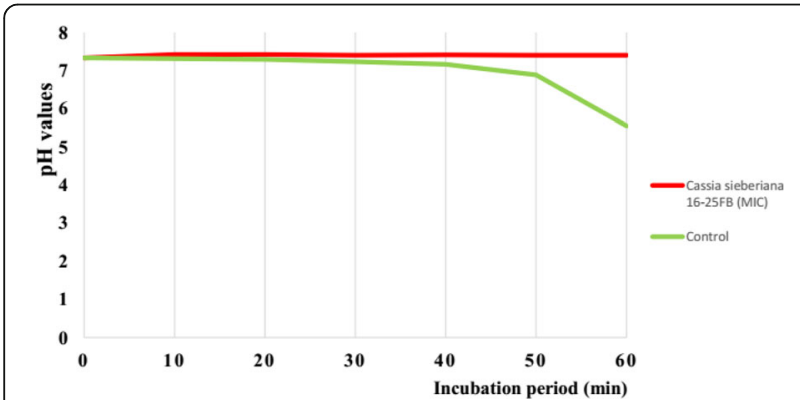

Fig. 3 Effect of sub-fraction CSBC2 on Escherichia coli ATCC8739 $\mathrm{H}^{+}$ATPase- dependent proton pumps

\section{Conclusion}

This work was aimed at contributing to the fight against infectious diseases caused by MDR bacteria phenotypes. Crude extract CSB, fraction CSBc and sub-fraction CSBc2 exhibited moderate antibacterial activities on several strains and their activities significantly increased in the presence of PA $\beta N$. Sub-fraction CSBc2 inhibited the cell growth at sub-inhibitory concentrations as well as bacterial $\mathrm{H}^{+}$-ATPases-dependent proton pumps. Compounds 1 (spectaline) was most active than other compounds. Results obtained validate the therapeutic usage of C. sieberiana bark in traditional medicine and indicate that their bioactive constituents can be combined to an efflux pumps inhibitor to overcome the problem of bacterial resistance involving efflux pumps. The mechanisms of action of this plant are reported for the first time in the present work. However, further studies about the combination of these plant constituents with commonly used antibiotics are important to efficiently fight against infectious diseases.

\section{Supplementary Information}

The online version contains supplementary material available at https://doi. org/10.1186/s12906-020-03148-3.

Additional file 1: Supplementary file. SF 1. Tables showing the fractionation and purification of C. sieberiana bark; SF 2. ${ }^{1} \mathrm{H}$ and ${ }^{13} \mathrm{C}$ NMR and major chemical shifts of studied compounds; G1. Data and graphic for the effect of sub-fraction CSBC2 on the bacterial growth kinetic; G2. Data and graphic for the effect of sub-fraction CSBC2 on bacterial $\mathrm{H}^{+}$ATPase-depending proton pumps.

\section{Abbreviations}

CSB: Cassia sieberiana; ATCC: American Type Culture Collection; MIC: Minimal inhibitory concentration; MBC: Minimal bactericidal concentration; DMSO: Dimethylsulfoxide; INT: p-lodonitrotetrazolium chloride; PABN: Phenylalanine arginine- $\beta$ - naphthylamide; SFR/CAM: Society of forest reserve of Cameroon; NHC: National herbarium of Cameroon;

CHL: Chloramphenicol; MHA: Mueller Hinton agar; MHB: Mueller Hinton broth; OD: Optical density; RND: Resistance-nodulation-cell division; EPI: Efflux pumps inhibitor; AlF: Activity improvement factor; NMR: Nuclear magnetic resonance; CC: Column Chromatography

\section{Acknowledgements}

The authors wish to autograph this work in memory for Pierre Tane (Professor) who was the supervisor of the chemical part of this work. We also thank the National Herbarium of Cameroon (Yaoundé) for plant identification.

\section{Authors' contributions}

VK and VBP designed the experiment and supervised; MMMA carried out the antibacterial testing; EBW and PN performed the mechanisms of action; BCKA, GTMB and JDSM performed the phytochemical studies; SBT, BCKA and GTMB wrote the manuscript; all authors read and approved the final manuscript.

\section{Funding}

No funding.

Availability of data and materials

All data generated or analyzed during this study are included in this published article and its supplementary information files. 


\section{Ethics approval and consent to participate}

Not applicable.

\section{Consent for publication}

Not applicable.

\section{Competing interests}

VK is a Section Editor of BMC Complementary and Alternative Medicine; all the other authors declare that they have no competing interests.

\section{Author details}

'Department of Biochemistry, University of Dschang, P.O. Box 67, Dschang, Cameroon. ${ }^{2}$ Department of Biochemistry, University of Yaounde 1, P.O. Box 812, Cameroun, Yaounde, Cameroon. ${ }^{3}$ Department of Chemistry, University of Dschang, P.O. Box 67, Dschang, Cameroon. ${ }^{4}$ Institute of Organic Chemistry, University of Mainz, Duesbergweg 10-14, D-55128 Mainz, Germany.

Received: 9 December 2019 Accepted: 5 November 2020

Published online: 12 November 2020

\section{References}

1. Dye C. Infectious diseases in a new era of health and development, "Philosophical Transactions of the Royal Society B". Biol Sci. 2015; 369(1645):2014

2. WHO. Déclaration conjointe OMS/UNICEF. Prise en charge d'une infection bactérienne potentiellement grave chez le jeune nourrisson âgé de 0 à 59 jours lorsqu'un transfert vers une structure hospitalière est impossible. Disponible sur http://www.who.int. Assessed on 15/09/18.

3. Lozano R, Naghavi M, Foreman K. Global and regional mortality from 235 causes of death for 20 age groups in 1990 and 2010: a systematic analysis for the Global Burden of Disease Study 2010. Lancet. 1990; 380(9859):2095-128.

4. Kuete V. Medicinal plant research in Africa. In: Kuete V, editor. Pharmacology and chemistry. Oxford: Elsevier; 2013.

5. Ashu FA, Na-lya J, Wamba BEN, Kamga J, Nayim P, Ngameni B, Beng VP, Ngadjui BT, Kuete V. Antistaphylococcal activity of extracts, fractions, and compounds of Acacia polyacantha wild (Fabaceae). Evid Based Complement Alternat Med. 2020:1-10. https://doi.org/10.1155/2020/2654247.

6. Youmbi LM, BCK A, Tankeo SB, BEN W, Nayim P, Nganou BK, GTM B, Simo IK, JDS M, Penlap VB, Victor K. Antibacterial potential and mechanism of action of botanicals and phytochemicals from Stachytarpheta cayennensis (Verbenaceae) against Gram-negative multidrug-resistant phenotypes expressing efflux pumps. Investig Med Chem Pharmacol. 2020;3(1):35. https://doi.org/10.31183/imcp.2020.00035.

7. Nayim P, Mbaveng TA, Wamba NEB, Fankam AG, Dzotam JK, Kuete V. Antibacterial and antibiotics-potentiating activities of thirteen Cameroonian edible plants against gram-negative resistant phenotypes. Sci World J. 2018: 1-14. https://doi.org/10.1155/2018/4020294.

8. Nguenang SG, Mbaveng TA, Fankam GA, Manekeng TH, Nayim P, Wamba NEB, Kuete V. Tristemma hirtum and five other Cameroonian edible plants with weak or no antibacterial effects modulate the activities of antibiotics against gram-negative multidrug-resistant phenotypes. Sci World J. 2018:112. https://doi.org/10.1155/2018/7651482.

9. Nguemeving JR, Azebaze AG, Kuete V, Eric Carly NN, Beng VP, Meyer M, Blond A, Bodo B, Nkengfack AE. Laurentixanthones a and B, antimicrobial xanthones from Vismia laurentii. Phytochemistry. 2006;67(13):1341-6.

10. Sam GH, Mensah MLK, Nyakoa-Ofori N. Pharmacognostic studies and standardization of Cassia sieberiana roots. Pharm J. 2011;3(21):12-7.

11. Harborne JB. Phytochemical methods: A guide to modern techniques of plant analysis (3e éd.). New york: Chapman and Hall Limited; 1998.

12. Evans WC. Trease and Evans Pharmacognosy. 15th ed. Elsevier: A Division of Reed Elsevier India Pvt. Limited; 2002. p. 585.

13. Kuete V, Ngameni B, Tangmouo JG, Bolla JM, Albert-Franco S, Ngadjui BT, Pagès J-M. Efflux pumps are involved in the defense of gram-negative bacteria against the natural products isobavachalcone and diospyrone. Antimicrob Agents Chemother. 2010a;54(5):1749-52.

14. Chevalier J, Pages JM, Eyraud A, Mallea M. Membrane permeability modifications are involved in antibiotic resistance in Klebsiella pneumoniae. Biochem Biophys Res Commun. 2000;274:496-9.
15. Lorenzi V, Muselli A, Bernardini AF, Berti L, Pages JM, Amaral L, Bolla JM. Geraniol restores antibiotic activities against multidrug-resistant isolates from gram-negative species. Antimicrob Agents Chemother. 2009;53:2209-11.

16. Mallea M, Mahamoud A, Chevalier J, Alibert-Franco S, Brouant P, Barbe J Pages JM. Alkylaminoquinolines inhibit the bacterial antibiotic efflux pump in multidrug-resistant clinicalisolates. Biochem J. 2003;376:801-5.

17. Tran Q-T, Mahendra KR, Hajjar A, Ceccarelli M, Davin-Regli A, Winterhalter M, Weingart $\mathrm{H}$, Pagès J-M. Implication of porins in B-lactam resistance of Providencia stuartii. J Biol Chem. 2010;285:32273-81.

18. Eloff JN. A sensitive and quick microplate method to determine the minimal inhibitory concentration of plant extracts for bacteria. Planta Med. 1998;64:711-3.

19. Mativandlela SPN, Lall N, Meyer JJM. Antibacterial, antifungal and antitubercular activity of (the roots of) Pelargonium reniforme (CURT) and Pelargonium sidoides (DC) (Geraniaceae) root extracts. S Afr J Bot. 2006;72(2): 232-7.

20. Kuete V, Ngameni B, Fotso SCC, Kengap TR, Tchaleu NB, Meyer JJM, et al. Antimicrobial activity of the crude extracts and compounds from Ficus chlamydocarpa and Ficus cordata (Moraceae). J Ethnopharmacol. 2008;120: $17-24$.

21. Cox SD, Mann CM, Markham JI, Bell HC, Gustafson JE, Warmington JR, Wyllie SG. The mode of antimicrobial action of the essential oil of Melaleuca alternifolia (tea tree oil). J Appl Microbiol. 2000;88:170-5.

22. Manavathu EK, Dimmock JR, Sarvesh CV, Chandrasekar PH. Inhibition of H+ATPase-mediated proton pumping in Cryptococcus neoformans by a novel conjugated styryl ketone. J Antimicrob Chemother. 2001;47:491-4.

23. Kuete V. Potential of Cameroonian plants and derived products against microbial infections: a review. Planta Med. 2010;76:1-13.

24. Gatsing D, Adoga Gl. Antisalmonellal activity and phytochemical screening of various parts of Cassia petersiana (cesulpiniaceae). Res J Microbiol. 2007;2: $876-80$.

25. Kuete V, Poumale Poumale HM, Guedem AN, Shiono Y, Randrianasolo R, Ngadjui BT. Antimycobacterial, antibacterial and antifungal activities of the methanol extract and compounds from Thecacoris annobonae (Euphorbiaceae). S Afr J Bot. 2010b;76:536-42.

26. Olajide O, Afolayan M, Adewusi AJ, Adeyanju O. Antimicrobial activity and elemental analysis of Cassia sieberiana leaves using atomic absorbtion spectrophotometer. J Nat Prod Plant Resour. 2012;2(1):9-18.

27. Awomukwu DA, Nyananyo BL, Ikpeama Al, Adieze CU. Comparative chemical constituents of some Cassia species and their pharmacognostic importance in south eastern Nigeria. Sci J Chem. 2015;3(3):40-9.

28. Traore A, Ouedraogo S, Bonewende BM, Kabore A, Guissou IP. Phytochemical analysis and ovicidal activity of Cassia sieberiana, Guiera senegalensis and Excoecaria grahamii extracts. Acad J. 2017;11(44):554-60.

29. Manekeng HT, Mbaveng AT, Nguenang GS, Seukep JA, Wamba BEN, Nayim $P$, Yinkfu NR, Kuete V. Anti-staphylococcal and antibiotic-potentiating activities of seven Cameroonian edible plants against resistant phenotypes. Investig Med Chem Pharmacol. 2018;1:7.

30. Modusolumuo AM, Nadro SM, Wurochekke UA. Antihepatotoxic properties of Cassia sieberiana in acetaminophen treated rats. Niger J Biochem Mol Biol. 1999:14:21-5.

31. Mohammed Z, Bello H, Abdullahi YH, Abdurrahman EM. Evaluation of antidiarrheal potential of methanolic root extract of Cassia Sieberiana Dc. (Fabaceae) in mice. Alt Med Chiropractic OAJ. 2019;2(2):180015.

32. Mahato SB, Nandy AK, Roy G. Triterpenoids and saponins. Phytochem. 1988; 27:3037-67.

33. Toma I, Karumi Y, Geidam MA. Phytochemical screening and toxicity studies of the aqueous extract of the pods pulp of Cassia sieberiana DC. (Cassia Kotchiyana Oliv.). Afr J Pure Appl Chem. 2009:3(2):026-30.

34. Nascimento GGF, Locatelli J, Freitas PC, Silva GL. Antibacterial activity of plant extracts and phytochemicals on antibiotic resistant bacteria. Braz $J$ Microbiol. 2000;31:247-56.

35. Aliyu AB, Musa AM, Abdullahi MS, Oyewale AO. Phytochemical and antibacterial properties of Ludwigia suffruticosa (Willd.) Oliv. Ex. O. Ktze (Onagraceae). Int J Pure Appl Sci. 2008;2(4):1-5.

36. Kpegba K, Eloh K, Evenamede KS, Afanyibo Y-G, Elomri A, Simalou O, Boyode P, Agbonon A, Seguin E. A comparative study of the chemical composition of the extracts from leaves, stem, bark, and root bark of Cassia sieberiana: antibacterial activities. Orient J Chem. 2019;35(6):1678-89.

37. Cowan MM. Plant products as antimicrobial agents. Clin Microbiol Rev. 1999;12:564-82 
38. Tankeo SB, Lacmata ST, Noumedem JAK, Dzoyem JP, Kuiate J-R, Kuete V. Antibacterial and antibiotic-potentiation activities of some Cameroonian food plants against multi-drug resistant gram-negative bacteria. Chin J Integr Med. 2014;20(7):546-54.

39. Kameda R, Sohma T, Kobayashi K, Uchiyama R, Nosaka K, Konno H, Akaji K, Hattori Y. Convergent synthesis of trans-2,6-disubstituted piperidine alkaloid, $(-\neg)$-iso-6-Spectaline by palladium-catalyzed cyclization. Chem Pharm Bull. 2019;67(3):253-7.

40. Sansores-Peraza P, Rosado-Vallado M, Brito-Loeza W, Mena-Rejon GJ, Quijano L. Cassine, an antimicrobial alkaloid from Senna racemosa. Fitoterapia. 2000;71:690-2.

41. Sain AA, Amanah A, Zahari Z, Salim RJM, Mansor SM, Adenan MI. (+)-Spectaline, a piperidine alkaloid from Senna spectabilis DC. effective in reducing the in vitro infection of Leishmania major. Int J Pharmacol Phytochemistry Ethnomed; ISSN: 2297-6922. 2016:3:1-8.

42. Pagès J-M, Amaral L. Mechanisms of drug efflux and strategies to combat them: challenging the efflux pump of gram-negative bacteria. Biochim Biophys Acta. 1794;2009:826-33.

43. Renau TE, Leger R, Flamme EM, Sangalang J, She MW, Yen R, Gannon CL, Griffith D, Chamberland S, Lomovskaya O, Hecker SJ, Lee VJ, Ohta T, Nakayama K. Inhibitors of efflux pumps in Pseudomonas aeruginosa potentiate the activity of the fluoroquinolone antibacterial levofloxacin. J Med Chem. 1999;42(24):4928-31.

44. Lomovskaya O, Zgurskaya HI, Totrov M, Watkins WJ. Waltzing transporters and the dance macabre between humans and bacteria. Nat Rev Drug Discov. 2007:6:56-65.

45. Tegos PG, Haynes M, Strouse JJ, Khan TMM, Bologa GC, Oprea IT, Sklar AL. Microbial efflux pump inhibition: tactiCSB and strategies. Curr Pharm Des. 2011;17(13):1291-302.

46. Askoura M, Mottawea W, Abujamel T, Taher I. Efflux pump inhibitors (EPIs) as new antimicrobial agents against Pseudomonas aeruginos a. Libyan J Med. 2011;6. https://doi.org/10.3402/ljm.v6i0.5870.

47. Fujita M, Shiota S, Kuroda T, Hatano T, Yoshida T, Mizushima T, Tsuchiya T. Remarkable synergies between baicalein and tetracycline, and baicalein and $\beta$-lactams against methicillin-resistant Staphylococcus aureus. Microbiol Immunol. 2005;49:391-6.

48. Bakli S. Activité antibactérienne des fractions chromatographiques des extraits phénoliques de Pistacia lentiscus (Mémoire en vue de l'obtention du diplôme de Magister en Biologie): Université Abderahmane Mira de Bejaia; 2010.

49. Padan E, Zilberstein D, Schuldiner S. pH homeostasis in bacteria. Biochim BiophysActa. 1981;650(2-3):151-66.

50. Kobayashi H. A proto-translocating of ATPase regulates $\mathrm{pH}$ of the bacterial cytoplasm. J Biol Chem. 1985;260(5):72-5.

\section{Publisher's Note}

Springer Nature remains neutral with regard to jurisdictional claims in published maps and institutional affiliations.

Ready to submit your research? Choose BMC and benefit from:

- fast, convenient online submission

- thorough peer review by experienced researchers in your field

- rapid publication on acceptance

- support for research data, including large and complex data types

- gold Open Access which fosters wider collaboration and increased citations

- maximum visibility for your research: over $100 \mathrm{M}$ website views per year

At $\mathrm{BMC}$, research is always in progress.

Learn more biomedcentral.com/submissions 